\title{
ANALISIS FAKTOR-FAKTOR YANG DIPERTIMBANGKAN DALAM PENENTUAN NISBAH BAGI HASIL SIMPANAN DEPOSITO MUDHARABAH DAN PERLAKUAN AKUNTANSINYA PADA BPR SYARIAH ASRI MADANI NUSANTARA
}

\author{
Nur Hisamuddin \\ Andi A. \\ Jurusan Akuntansi Fakultas Ekonomi \\ Universitas Jember
}

\begin{abstract}
This title of this research, namely analysis that Infuenced considered in the determination of the odds for the results of Deposit Mudharabah deposits and His Accounting Treatment on Bpr Syariah Asri Civil Society of the Archipelago. The purpose of this research is as follows: to know the factors that are considered in the determination of the odds for the results of deposit mudharabah on BPR Syariah Asri Civil Society Nusantara, to know the recognition and measurement, presentation and disclosure of deposit mudharabah on BPR Syariah Asri Civil Society archipelago have been in accordance with the PSAK 105. Qualitative research method descriptive analysis. Research Results concluded that the factors that are considered in the determination of the odds for the results of deposit mudharabah on BPR Syariah Asri Civil Society of the archipelago is the rate that applies in other sharia banks and conventional banks based on financial performance; good relationship between bank with a partner or client; the work plan of the annual budget and the placement of the funds between Bank (intercity in the whole of Indonesia); macro economic.
\end{abstract}

Key words: Odds for the results, Mudharabah, Mudharabah Deposits

\section{A. Pendahuluan}

Bank syariah adalah bank yang aktivitasnya meninggalkan masalah riba. Bank syariah beroperasi tidak dengan menerapkan metode bunga, melainkan dengan metode bagi hasil dan penentuan biaya yang sesuai dengan syariah islam. Dengan demikian, penghindaran bunga yang dianggap riba merupakan salah satu yang dihadapi dunia islam dewasa 
ini. Belakangan ini para ekonom muslim telah mencurahkan perhatian besar guna menemukan cara untuk menggantikan sistem bunga dalam transaksi perbankan dan keuangan yang lebih sesuai dengan etika Islam. (Machmud dan Rukmana, 2010:4)

Perkembangan yang pesat pada bank syariah di Indonesia semakin berkembang karenaselama ini bank syariah mampu membidik pasar syariah loyalis, yaitu konsumen yang meyakini bahwa bunga bank itu haram. Di lain pihak, bank syariah sedang mengalami kondisi persaingan yang sangat ketat karena semua pihak yang terlibat dalam perbankan sama-sama bergerak di pasar rasional yang sensitif terhadap bunga. Para depositor sendiri sangat memperhatikan return atau keuntungan yang mereka peroleh ketika menginvestasikan uangnya di bank (Anisah dkk, 2013).

Menurut Timami dan Soejoto (2013),munculnya bankbank syariah tersebut didasari dari kesadaran adanya bahaya riba bagi orang-orang muslim dari sistem yang dianut oleh bank konvensional. Maka dari itu, bank syariah menawarkan jasa perbankan penghimpunan dana dengan menggunakan sistem bagi hasil dalam pembagian keuntungan maupun kerugian agar terhindar dari bahaya riba.Fungsi dasar bank syariah secara umum tidak jauh berbeda dengan bank konvensional., sehingga prinsip umum dalam pengaturan dan pengawasan bank yang diberlakukan pada bank konvensional juga terdapat pada bank syariah. Namun, terdapat perbedaan yang cukup mendasar dalam operasional bank syariah, yaitu:

a. Perlunya jaminan pemenuhan ketaatan pada prinsip syariah dalam seluruh aktivitas bank.

b. Perbedaan karakteristik operasional khususnya adanya pelarangan bunga dengan prinsip bagi hasil.

Proses penentuan tingkat bagi hasil diperlukan kesepakatan kedua belah pihak yang terungkap dalam nisbah bagi hasil. Dalam bank syariah, penentuan nisbah bagi hasil hampir sama dengan proses perhitungan biaya dana dan perhitungan tingkat bunga pembiayaan pada bank konvensional. Namun dengan penekanan berbeda, karena bank konvensional berbasiskan biaya sedangkan bank syariah berbasiskan pendapatan yang menekankan keadilan melalui 
pembagian risiko sesuai kesepakatan diawal perjanjian (Rivai dan Arifin, 2010:799).

Pada bank syariah, nasabah dapat menentukan jenis program yang dipilih untuk menanamkan atau menyimpan harta mereka. Adapun beberapa program pengembangan produk bank syariah yang dapat dipilih oleh nasabah, seperti: (Muhammad, 2013:181),

1. Produk Penghimpunan Dana, melalui mekanisme giro, tabungan, dan deposito. Tabungan dan giro didasarkan pada akad wadi'ah dan akad mudharabah. Sedangkan khusus deposito hanya memakai akad mudharabah.

2. Produk Penyaluran Dana, dapat ditempuh oleh bank dalam bentuk murabahah, mudharabah, musyarakah, ataupun qardh.

3. Produk Jasa, dapat berupa penyediaan bank garansi (kafalah), Letter of Credit, Hiwalah, Wakalah, dan jual beli valuta asing.

Semakin berkembangnya kegiatan perekonomian perlu adanya sumber untuk menyediakan dana guna membiayai kegiatan usaha. Dalam hal ini bank syariah mempunyai kedudukan yang penting untuk menghimpun dana. Deposito mudharabah akan mempunyai kedudukan yang sangat istimewa. Penelitian ini, penulis lebih menfokuskan untuk meneliti penghimpunan dana dengan mekanisme deposito dengan menggunakan akad mudharabah, karena deposito mudharabah yang paling sesuai dengan prinsip bagi hasil di dalam penerapannya. Deposito yang dibenarkan berdasarkan syariah adalah deposito dengan prinsip mudharabah, dalam prinsip mudharabah pihak bank syariah berfungsi sebagai pengelola dana yang dapat menginvestasikan dananya pada usaha-usaha yang tidak bertentangan dengan prinsip syariah. Modal yang didepositokan harus dinyatakan secara tunai. Sebagai mudharib, bank menutup biaya operasional dengan menggunakan nisbah keuntungan yang menjadi haknya dan bank tidak diperkenankan mengurangi nisbah keuntungan nasabah tanpa persetujuan nasabah yang bersangkutan (Salman, 2012:133).

Deposito berdasarkan akad mudharabah adalah: (Majelis Ulama Indonesia dalam Anisah, dkk, 2013)

1. dalam transaksinya nasabah bertindak sebagai shahibul 
maal atau pemilik dana, dan bank bertindak sebagai mudharib atau pengelola dana;

2. dalam kapasitasnya sebagai mudharib, bank dapat melakukanberbagaimacamusahayangtidakbertentangan dengan prinsip syari'ah dan mengembangkannya, termasuk di dalamnya mudharabah dengan pihak lain;

3. modal harus dinyatakan dengan jumlahnya dalam bentuk tunai dan bukan piutang;

4. pembagian keuntungan harus dinyatakan dalam bentuk nisbah dan dituangkan dalam akad pembukaan rekening;

5. bank sebagai mudharib menutup biaya operasional deposito dengan menggunakan nisbah keuntungan yang menjadi haknya;

6. bank tidak diperkenankan untuk mengurangi nisbah keuntungan nasabah tanpa persetujuan yang bersangkutan.

Bank syariah memiliki faktor-faktor yang dipertimbangkan dalam menentukan nisbah bagi hasil deposito mudharabah.Faktor yang dipertimbangkan dalam penentuan nisbah bagi hasil di setiap bank penting adanya diterapkan dan diberlakukan sebagai pedoman untuk memberikan ketentuanketentuan tentang pemberian nisbah yang ditetapkan oleh pihak bank untuk para nasabahnya menginvestasikan atau menanamkan hartanya dengan sistem bagi hasil sesuai dengan kesepakatan yang sudah diperjanjikan di awal perjanjian. Dalam penelitian ini juga dijelaskan perlakuan akuntansi atas deposito yang menggunakan akad mudharabah sebagai penghimpun dana yang akan dibandingkan dengan Pernyataan Standar Akuntansi Keuangan (PSAK) No. 105 tentang akuntansi mudharabah karena pada PSAK ini ditujukan untuk mengatur pengakuan dan pengukuran, penyajian, serta pengungkapan transaksi. Pernyataan ini diterapkan untuk entitas yang melakukan transaksi mudharabah baik sebagai pemilik dana (shahibul maal) maupun pengelola dana (mudharib). Penulis memilih salah satu bank yang berpusat di kota Jember adalah Bank Perkreditan Rakyat (BPR) Syariah Asri Madani Nusantara, sehingga penulis akan melakukan analisis penelitian yang dilakukan pada BPR Syariah tersebut.

Adapun alasan penulis melakukan penelitian pada bank 
tersebut karena BPRS ASRI merupakan BPR Syariah pertama di Kabupaten Jember. Pada saat BPR Syariah mengalami perubahan kepemilikan, perbaikan manajemen dan kinerja mulai membuahkan hasil.PT. BPRS Asri Madani Nusantara mendapat penghargaan The Best Sharia Finance Award 2013 dari Majalah Infobank. Selain itu, PT. BPRS Asri Madani Nusantara termasuk dalam 6 besar BPRS dengan Kinerja "Sangat Bagus" se-Indonesia (penilaian Desember 2011 - Desember 2012) untuk kategori BPR Syariah dengan aset dibawah 10 miliar rupiah.

Menurut penelitian sebelumnya (Oksita, 2011), tentang faktor-faktor yang dipertimbangkan dalam penentuan nisbah bagi hasil atas pembiayaan mudharabah pada BMT di Kabupaten Situbondo dengan melakukan objek penelitian di tiga BMT dapat disimpulkan faktor-faktor yang dipertimbangkan meliputi, besar kecilnya nominal pembiayaan, jangka waktu pengembalian, sektor usaha yang dijalankan, besarnya jaminan mudharib, perkiraan resiko yang dihadapi, dan hubungan baik antara mitra dan BMT.Dalam perlakuan akuntansinya, menurut Bimo (2013), tentang perlakuan atas pembiayaan mudharabah pada BMT syariah adalah dapat dimpulkan bahwa perlakuan akuntansi yang diterapkan oleh BMT Bina Tanjung dapat dikatakan telah sesuai dengan PSAK 105 kesesuaian tersebut terdapat pada karakteristik dan pengungkapan, kecuali pada pengakuan, pengukuran dan penyajian, sedangkan untuk BMT UGT Sidogiri telah sesuai dengan PSAK 105, kesesuaian tersebut terdapat pada karakteristik, pengakuan, pengukuran, pengungkapan, kecuali pada penyajian.

Berdasarkan latar belakang yang telah dipaparkan, maka peneliti tetarik untuk melakukan penelitian mengenai faktor-faktor yang diperimbangkan dalam bagi hasil simpanan deposito mudharabah pada bank syariah dan menganalisis perlakuan akuntansinya yang diterapkan oleh BPR Asri Madani Nusantarauntuk kesesuaian menurut PSAK 105 tentang perbankan syariah. Oleh sebab itu, peneliti mengajukan skripsi yang berjudul "Analisis Faktor-Faktor yang Dipertimbangkan Dalam Penentuan Nisbah Bagi Hasil Simpanan Deposito Mudharabah dan Perlakuan Akuntansinya pada BPR Syariah Asri Madani Nusantara".

Tujuan dari penelitian ini adalah sebagai berikut: 
untuk mengetahui faktor-faktor yang dipertimbangkan dalam penentuan nisbah bagi hasil depositomudharabah pada BPR Syariah Asri Madani Nusantara, untuk mengetahui pengakuan dan pengukuran, penyajian, serta pengungkapan deposito mudharabah pada BPR Syariah Asri Madani Nusantara telah sesuai dengan PSAK 105.

\section{B. Tinjauan Pustaka}

\section{Pengertian Bank Syariah}

Bank syariah merupakan bank yang kegiatannya mengacu pada hukum islam, dan alam kegiatannya tidak membebankan bunga, kepada nasabah. Imblan yang diterima oleh bank syariah, maupun yang dibayarkan kepada nasabah tergantung dari akad dan perjanjian antara nasabah dan bank. Perjanjian tersebut didasarkan pada hukum syariah baik perjanjian yang dilakukan bank dengan nasabah dalam penghimpunan dana, maupun penyalurannya. Perjanjian yang terdapat di perbankan syariah harus tunduk pada syarat dan rukun akad tersebut ( Ismail, 2010:20).

Menurut Wibowo dan Hendy (2005:33), bank syariah adalah bank yang beroperasinya mengikuti ketentuanketentuan syariah islam, khususnya yang menyangkut tata cara bermuamalah secara islam. Dalam tata cara bermaumalat itu dijauhi praktik yang dikhawatirkan dan mengandung unsur riba. Kegiatan bank syariah ini diisi dengan kegiatan investasi atas dasar bagi hasil. Falsafah dasar beroperasinya bank syariah yang menjiwai seluruh hubungan transaksinya adalah efisiensi, keadilan, dan kebersamaan.

Pada intinya bank dapat didefinisikan sebagai suatu badan usaha yang menghimpun dana dari masyarakat dalam bentuk simpanan dan menyalurkannya kepada masyarakat dalam rangka meningkatkan taraf hidup masyarakat banyak. Sesuai dengan Undang-undang Perbankan Syariah No. 21 Tahun 2008 menyatakan bahwa perbankan syariah adalah segala sesuatu yang menyangkut tentang bank syariah dan unit usaha syariah, mencakup kelembagaan, kegiatan usaha, serta cara dan proses dalam melaksanakn kegiatan usahanya. Beberapa contoh bank syariah antara lain Syariah Mandiri, Muamalat Indonesia, BNI Syariah, Permata Syariah, dan BRI Syariah (LSPP-IBI, 2014:2) 
Analisis Faktor-Faktor yang Dipertimbangkan dalam ...

\section{Karakteristik Bank Syariah}

Bank syariah memiliki beberapa karakteristik tertentu yang membedakannya dengan bank konvensional, yaitu sebagai berikut (Triyuwono, 2007):

a. metode bunga digantikan dengan metode bagi hasil yang menjadi ciri khas dari bank syariah;

b. dalam hal bank mengalami kerugian, nasabah penyimpan dana mungkin kehilangan dananya, menurut perbandingan pembagian laba/rugi;

c. beban biaya atas pelayanan bank syariah disepakati bersama saat akad pinjaman atau pembiayaan dinyatakan dalam bentuk nominal dengan istilah sesuai dengan produk yang ditawarkan. Besarnya beban biaya tersebut tidak kaku dan masih dapat dilakukan tawar menawar dalam batas yang wajar. Beban biaya tersebut hanya dikenakan selama masa berlakunya kontrak.

\section{Tugas dan Fungsi Bank Syariah}

Bank syariah memiliki tugas dan fungsi yang menjadi tujuan untuk melakukan kegiatan operasional berdasarkan prinsip syariah. Adapun tugas dan fungsi tersebut adalah sebagai berikut: (LSPP-IBI, 2014:3)

a. menunjang pelaksanaan pembangunan nasional dalam rangka meningkatkan keadilan, kebersamaan dan pemerataan kesejahteraan rakyat;

b. bank syariah dan Unit Usaha Syariah (UUS) wajib menjalankan fungsi sosial dalam bentuk lembaga baitul maal, yaitu menerima dana yang berasal dari zakat, infak, sedekah, hibah, atau dana sosial lain dan menyalurkannya kepada organisasi pengelola zakat;

c. bank syariah dan UUS dapat menghimpun dana sosial yang berasal dari wakaf sesuai dengan kehendak pemberi wakaf. Pelaksanaan fungsi sosial tersebut diatur oleh undang-undang.

\section{Sistem Operasional Bank Syariah}

Bank syariah sebagai lembaga keuangan juga harus melaksanakan mekanisme penghimpunan dana dan penyaluran dana secara seimbang, yaitu harus sesuai dengan ketentuan 
perbankan yang berlaku. Untuk itu harus ada kejelasan sistem operasional perbankan. Secara umum, konsep sistem operasional bank syariah adalah: (Yaya, dkk, 2014:51)

a. Sitem operasional bank syariah dimulai dari kegiatan penghimpunan dana dari masyarakat. Penghimpunan dana dapat dilakukan dengan skema investasi maupun skema titipan. Dalam penghimpunan dana skema investasi dari nasabah pemilik dana (shahibul maal), bank syariah berperan sebagai pengelola dana atau biasa disebut dengan mudharib. Adapun pada penghimpunan dengan skema penitipan, bank syariah berperan sebagai penerima titipan.

b. Dana yang diterima oleh bank syariah selanjutnya disalurkan kepada berbagai pihak, antara lain mitra investasi, pengelola investasi, pembeli barang dan penyewa barang atau jasa yang disediakan oleh bank syariah. Pada saat dana disalurkan dalam bentuk investasi, bank syariah berperan sebagai pemilik dana. Pada saat dana disalurkan dalam kegiatan jual beli, bank syariah berperan sebagai penjual dan pada saat disalurkan dalam kegiatan pengadaan objek sewa, berperan sebagai pemberi sewa.

c. Dari penyaluran dana kepada berbagai pihak, bank syariah selanjutnya menerima pendapatan berupa bagi hasil dari investasi, margin dari jual beli dan fee dari sewa dan berbagai jenis pendapatan yang diperoleh dari instrumen penyaluran dana lain yang diperbolehkan.

d. Pendapatan yang diterima dari kegiatan penyaluran selanjutnya dibagikan nasabah pemilik dana atau penitip dana. Penyaluran dana kepada pemilik dana bersifat wajib sesuai dengan porsi bagi hasil yang disepakati. Adapun penyaluran dana kepada nasabah penitip dana bersifat sukarela tanpa ditetapkan di muka sebelumnya dan biasa disebut dengan istilah bonus.

e. Selain melaksanakan aktivitas penghimpunan dana dan penyaluran, bank syariah dalam sistem operasionalnya juga memberikan layanan jasa keuangan seperti jasa ATM, transfer, letter of credit, bank garansi dan lain sebagainya. 
Analisis Faktor-Faktor yang Dipertimbangkan dalam ...

Sistem operasional bank syariah dapat disimpulkan terdiri atas sistem penghimpunan, sistem penyaluran dana yang dihimpun, dan sistem penyediaan jasa keuangan yang diperuntukkan pada nasabah yang akan menginvestasikan atau menyimpan harta mereka.

\section{Produk Operasional Bank Syariah}

Pada sistem operasi bank syariah, pemilik dana menanamkan uangnya di bank tidak dengan motif mendapatkan bunga, tetapi dengan maksud untuk mendapatkan keuntungan bagi hasil, dengan perjanjian keuntungan sesuai kesepakatan. Menurut Muhammad (2013:181), pengembangan produk bank syariah dikelompokkan menjadi tiga, yaitu:

a. produk penghimpunan dana, melalui mekanisme giro, tabungan, dan deposito. Tabungan dan giro didasarkan pada akad wadi'ah dan akad mudharabah. Sedangkan khusus deposito hanya memakai akad mudharabah;

b. produk penyaluran dana, dapat ditempuh oleh bank dalam bentuk murabahah, mudharabah, musyarakah, ataupun qardh;

c. produk jasa, dapat berupa penyediaan bank garansi (kafalah), Letter of Credit, Hiwalah, Wakalah, dan jual beli valuta asing.

\section{Bagi Hasil}

\section{a. Pengertian Bagi hasil}

Menurut Rivai dan Arifin (2010:800), bagi hasil adalah bentuk return (perolehan aktivitas usaha) dari kontrak investasi, dari waktu ke waktu, tidak pasti dan tidak tetap pada bank syariah. Besar kecilnya perolehan kembali itu tergantung pada hasil usaha yang benar-benar diperoleh bank syariah. Dimana besarnya porsi besarnya bagi hasil antara kedua belah pihak ditentukan sesuai kesepakatan bersama dan harus terjadi dengan adanya kerelaan oleh masing-masing pihak tanpa adanya unsur paksaan.Bagi hasil adalah bentuk perolehan kembaliannya dari kontrak suatu investasi, dan dari waktu ke waktu, serta tidak pasti dan tidak tetap, karena besar kecilnya suatu perolehan tergantung pada hasil usaha yng dijalankan.

Bagi hasil adalah sistem pembagian hasil usaha 
dimana pemilik modal bekerjasama dengan pemilik modal untuk melakukan kegiatan usaha. Apabila kegiatan usaha menghasilkan keuntungan maka dibagi berdua dan ketika mengalami kerugian ditanggung bersama pula. Sistem bagi hasil menjamin adanya keadilan dan tidak ada pihak yang tereksploitasi (Ascarya, 2006:26).

\section{b. Konsep Perhitungan Bagi Hasil}

Ada dua konsep dalam pembagian bagi hasil yang dapat dilakukan oleh bank syariah, yaitu profit sharing dan revenue sharing. Profit sharing adalah sistem pembagian bagi hasil yang proses perhitungannya berdasarkan laba bersih yang diperoleh oleh bank syariah dan jika terjadi kerugian, kerugian tersebut ditanggung oleh pemilik modal (Yuliana 2013). Sedangkan menurut Karim (2012), revenue sharing merupakan dasar perhitungan yang berasal dari pendapatan sebelum dikurangi beban atau biaya dan jika dalam usaha terjadi kerugian berarti kerugian tersebut ditanggung oleh pelaksana usaha.

Bank syariah lebih memilih menggunakan konsep revenue sharing karena pendapatan yang diterima belum dikurangi dengan biaya-biaya yang telah dikeluarkan untuk memperoleh pendapatan tersebut dan kemudian nisbah akan dibagikan pada pihak bank maupun nasabah sesuai dengan kontrak perjanjian yang sudah disepakati. Dimana untung dan rugi akan ditanggung oleh kedua belah pihak yang bekerja sama.

\section{c. Faktor yang Mempengaruhi Bagi Hasil}

Faktor-faktor yang mmpengaruhi bagi hasil terdiri dari (Antonio, 2001:139-140):

1) Faktor langsung

- Investment Rate

Persentase aktual dana yang diinvestasikan dari total dana yang diperoleh dari bank. Jika bank menentukan investment rate $85 \%$, hal ini berarti $15 \%$ dari total dana adalah sisa dana yang diinvestasikan merupakan dana yang dialokasikan untuk memenuhi likuiditas.

- Jumlah dana yang tersedia untuk diinvestasikan Jumlah dana dari berbagai sumber dana yang tersedia untuk diinvestasikan. Dana tersebut dapat dihitung 
Analisis Faktor-Faktor yang Dipertimbangkan dalam ...

menggunakan salah satu metode ini:

- Rata-rata saldo minimum bulanan.

- Rata-rata saldo harian.

Investment rate dikalikan dengan jumlah dana yang tersedia untuk diinvestasikan, akan menghasilkan jumlah dana aktual yang digunakan.

- Nisbah (profit sharing ratio)

Rasio yang harus disetujui dan ditentukan pada awal perjanjian antara pihak nasabah dengan pihak bank.

2) Faktor tidak langsung

- Penenetuan butir-butir pendapatan dan biaya mudharabah

- Bank dan nasabah akan melakukan share baik dalam pendapatan maupun biaya. Pendapatan yang dibagi hasilkan merupakan pendapatan yang diterima setelah dikurangi biaya-biaya.

- Jika semua biaya ditanggung oleh bank, hal ini disebut revenue sharing.

3) Kebijakan akunting (prinsip dan metode)

Bagi hasil secara tidak langsung dipengaruhi oleh berjalannya aktivitas yang diterapkan, terutama sehubungan dengan kebijakan akuntansi mengenai pengakuan pendapatan dan biaya.

Terdapat faktor yang mempengaruhi bagi hasil , seperti faktor langsung dan tidak langsung. Dalam penerapan di bank syariah, tidak semua faktor-faktor tersebut ada didalam ketentuan yang diberlakukan oleh pihak bank. Selain itu, dapat juga faktor-faktor yang dipertimbangkan untuk bagi hasil digunakan oleh bank lebih dari yang sudah ditetapkan.

\section{d. Bentuk Pengungkapan Bagi Hasil}

Adapun tata cara distribusi bagi hasil yang perlu diungkapkan dan disampaikan kepada nasabah, antara lain: (Rivai dan Arifin, 2010:801)

1) metode digunakan bank, sebagai dasar penentuan bagian keuntungan atau kerugian dari dana mudharabah tersebut;

2) tingkat pengembalian dana mudharabah; 
3) tingkat nisbah keuntungan yang telah disepakati dari setiap dana investasi.

\section{e. Tahap Perhitungan Bagi Hasil}

Untuk menetapkan bagi hasil terdapat tahap yang perlu diperhatikan dalam setiap kebijakan setiap bank yang sudah ditetapkan, antara lain: (Putra, 2012)

1) menentukan prinsip perhitungan bagi hasil;

2) menghitung jumlah pendapatan yang akan didistribusi;

3) menentukan sumber pendanaan yang digunakan sebagai dasar perhitungan bagi hasil;

4) menentukan pendapatan bagi hasil untuk bank atau nasabah;

5) akuntansi bagi hasil untuk bank syariah.

\section{f. Nisbah Bagi Hasil}

Proses penentuan tingkat bagi hasil diperlukan kesepakatan kedua belah pihak yang terungkap dalam nisbah bagi hasil. Dalam bank syariah, penentuan nisbah bagi hasil hampir sama dengan proses perhitungan biaya dana dan perhitungan tingkat bunga pembiayaan pada bank konvensional. Namun dengan penekanan berbeda, karena bank konvensional berbasiskan biaya sedangkan bank syariah berbasiskan pendapatan yang menekankan keadilan melalui pembagian risiko sesuai kesepakatan diawal perjanjian (Rivai dan Arifin, 2010:799).

Mudarabah harus menetapkan nisbah bagi hasil bagi masing-masing pihakyang berupa rasio (nisbah) bukan jumlah tertentu. Dalam sistem bagi hasil ini,pihak-pihak yang terlibat didalamnya harus melakukan transparansi dan kemitraansecara baik dan ideal. Besarnya nisbah ditentukan berdasarkan kesepakatan masing-masing pihak yang berakad. Jadi, angka besaran nisbah ini muncul sebagai hasil tawar antara sahibul maal dan mudharib. Dengan demikian, angka nisbah ini bervariasi, bisa 50:50 (dibaca 50 berbanding 50), 60:40, 70:30 dan seterusnya. Namun para ahli fiqih sepakat bahwa nisbah 100:0(dibaca 100 berbanding nol) tidak diperbolehkan (Siddiqi, 1996:206-209).

Menurut Adiwarman Karim, dalam Oksita (2011), hal hal yang berkaitan dengan nisbah bagi hasil yaitu: 
Analisis Faktor-Faktor yang Dipertimbangkan dalam ...

\section{1) Prosentase}

Nisbah keuntungan harus didasarkan dalam bentuk prosentase antara kedua belah pihak, bukan dinyatakan dalam nilai nominal rupiah tertentu. Nisbah keuntungan itu misalnya 50:50, 70:30, 60:40, atau 99:1. Jadi nisbah keuntungan ditentukan berdasarkan kesepakatan, bukan berdasarkan porsi setoran modal. Nisbah keuntungan tidak boleh dinyatakan dalam bentuk nominal rupiah tertentu, misalnya shahibul maal mendapat Rp. 50.000,00 dan mudharib mendapat Rp. 50.000,00.

2) Bagi Untung dan Bagi Rugi

Ketentuan prosentase tersebut merupakan konsekuensi logis dari karakteristik akad mudharabah itu sendiri, yang tergolong dalam kontrak investasi. Dalam kontrak ini, return dan timing cash flow kita tergantung kepada kinerja sektor riilnya. Bila laba bisnisnya besar, kedua belah pihak mendapat bagian yang besar pula. Bila laba bisnisnya kecil, mereka mendapat bagian yang kecil juga. Filosofi ini hanya dapat berjalan jika nisbah laba ditentukan dalam bentuk prosentase, bukan dalam bentuk nominal tertentu.

Bila dalam akad mudharabah ini mendapatkan kerugian, pembagian kerugian itu bukan didasarkan atas nisbah, tetapi berdasarkan porsi modal masingmasing pihak. Itulah alasan mengapa nisbahnya disebut sebagai nisbah keuntungan, bukan nisbah saja, karena nisbah 50:50, atau 99:1 itu hanya ditetapkan bila bisnisnya untung. Bila bisnisnya rugi, kerugiannya itu harus dibagi berdasarkan porsi masing-masing pihak, bukan berdasarkan nisbah. Hal ini karena adanya perbedaan kemampuan untuk menanggung kerugian diantara kedua belah pihak. Bila untung, tidak ada masalah untuk menikmati untung. Karena seberapapun keuntungan yang terjadi, kedua belah pihak akan selalu dapat menikmati keuntungan itu. Lain halnya kalau bisnisnya mengalami kerugian. Kemampuan shahibul maal untuk menanggung kerugian finansial tidak sama dengan kemampuan mudharib. Dengan demikian, karena kerugian dibagi berdasarkan proporsi modal shahibul 
maal dalam kontrak ini adalah $100 \%$ pula oleh shahibul maal. Di lain pihak, karena proporsi modal mudharib dalam kontrak ini adalah $0 \%$ lalu terjadi kerugian, mudharib akan menanggung kerugian sebesar $0 \%$ pula.

Apabila bisnis rugi, sesungguhnya mudharib akan menanggung kerugian hilangnya kerja, usaha, dan waktu yang telah dilakukan untuk menjalankan bisnis tersebut. Kedua belah pihak sama-sama menanggung kerugian, tetapi bentuk kerugian yang ditanggung oleh keduanya berbeda, sesuai dengan objek mudharabah yang telah dikontribusi. Bila yang dikontribusikan adalah uang, risikonya adalah hilangnya uang tersebut. Sedangkan bila yang dikontribusikan adalah kerja, risikonya adalah hilangnya kerja, usaha dan waktunya, sehingga tidak mendapatkan hasil apapun selama bisnis berlangsung.

3) Jaminan

Ketentuan pembagian kerugian, bila terjadi kerugian hanya murni diakibatkan oleh risiko binis, bukan karena risiko karakter buruk mudharib. Bila kerugian terjadi karena karakter buruk misalnya, karena mudharib lalai atau melanggar persyaratan kontrak mudharabah, maka shahibul maal tidak perlu menanggung kerugian.

Pihak mudharib yang lalai atau menyalahi kontrak, maka shahibul maaldiperbolehkan meminta jaminan tertentu kepada mudharib. Jaminan ini akan disita oleh shahibul maal jika ternyata timbul kerugian karena mudharib melakukan kesalahan, yaitu lalai dan ingkar janji. Kerugian yang timbul karena faktor resiko bisnis, jaminan mudharib tidak dapat disita oleh shahibul maal. Cara penyelesaiannya adalah jika salah satu pihak tidak menunaikan kewajibannya atau jika terjadi perselisihan diantara kedua belah pihak, maka penyelesaiannya dilakukan melalui Badan Arbitrasi Syariah setelah tidak tercapai kesepakatan melalui musyawarah.

\section{Mudharabah}

\section{a. Pengertian Mudharabah}

Mudharabah adalah perjanjian atas suatu jenis kerja sama usaha dimana pihak pertama menyediakan dana dan 
pihak kedua bertanggung jawab atas pengelolaan usaha. Pihak yang menyediakan dana biasa disebut dengan istilah shahibul maal, sedangkan pihak yang mengelola usaha disebut dengan mudharib. Keuntungan hasil usaha dibagikan sesuai dengan nisbah bagi hasil yang disepakati bersama sejak awal. Akan tetapi, jika terjadi kerugian, shahibul maal akan kehilangan imbalan dari hasil kerjanya selama proyek berlangsung (Yaya, dkk, 2014:53).

Menurut Rivai, dkk (2013:197), mudharabah adalah suatu persetujuan antara suatu penyedia modal (bank) dan pihak lain (wirausaha) untuk memungkinkan menyelesaikan suatu proyek bisnis yang dijalankan. Ini didasarkan atas pembagian laba sebelum kesepakatan kontrak yang telah disetujui. Jika mengalami kerugian, kerugian itu ditanggung oleh penyedia dana. Bank tidak akan menghalangi bisnis tetapi lebih memberi mitra yang tidak terikat untuk menjalankannya

Mudharabah merupakan akad bagi hasil ketika pemilik dana/ modal (pemodal), biasa disebut shahibul maal/ rabbul maal, menyediakan modal (100 persen) kepada pengusaha sebagai pengelola, biasa disebut mudharib, untuk melakukan aktivitas produktif dengan syarat bahwa keuntungan yang dihasilkan akan dibagi di antara mereka menurut kesepakatan yang ditentukan sebelumnya dalam akad (yang besarnya juga dipengaruhi oleh kekuatan pasar) (Ascarya, 2006:60).

\section{b. Rukun dan Ketentuan Mudharabah}

Menurut Salman (2012:223-224) rukun dan akad mudharabah ada empat, yaitu:

1) Pelaku, terdiri atas: pemilik dana dan pengelola dana

- pelaku harus cakap hukum dan balig;

- pelaku akad mudharabah dapat dilakukan sesama atau dengna non muslim;

- pemilik dana tidak boleh ikut campur dalam pengelolaan usaha tetapi ia boleh mengawasi

2) Objek Mudharabah, berupa modal dan kerja

Objek mudharabah merupakan konsekuensi logis dengan dilakukannya akad mudharabah. Berikut penjelasan modal dan kerja.

a) Modal 
Beberapa penjelasan yang terkait dengan modal adalah:

- modal yang diserahkan dapat berbentuk uang atau aset lainnya, harus jelas jumlah dan jenisnya;

- modal diberikan secara tunai dan tidak utang. Tanpa adanya setoran modal, berarti pemilik dana tidak memberikan kontribusi apapun padahal pengelola dana harus bekerja;

- modal harus diketahui dengan jelas jumlahnya sehingga dapat dibedakan dari keuntungannya;

- pengelola dana tidak diperkenankan untuk memudharabahkan kembali modal mudharabah, dan apabila terjadi maka dianggap pelanggaran kecuali atas seizin pemilik dana;

- pengelola dana tidak diperbolehkan untuk meminjamkan modal kepada orang lain dan apabila terjadi maka dianggap pelanggaran kecuali atas seizin pemilik dana;

- pengelola dana memiliki kebebasan untuk mengatur modal menurut kebijaksanaan dan pemikirannya sendiri, selama tidak dilarang secara syariah.

b) Kerja

Beberapa penjelasan terkait dengan kerja adalah:

- kontribusi pengelola dana dapat berbentuk keahlian, keterampilan, selling skill, management skill, dan lain-lain;

- kerja adalah hak pengelola dana dan tidak boleh diintervensi oleh pemilik dana;

- pengelola dana harus menjalankan usaha sesuai dengan syariah;

- pengelola dana harus mematuhi semua ketetapan yang ada dalam kontrak;

- dalam hal pemilik dana tidak melakukan kewajiban atau melaksanakan pelanggaran 
Analisis Faktor-Faktor yang Dipertimbangkan dalam ...

terhadap kesepakatan, pengelola dana sudah menerima modal dan sudah bekerja, maka pengelola dana berhak mendapatkan imbalan/ganti rugi/upah.

c) Ijab Kabul/Serah Terima;

Pernyataan dan ekspresi saling rida/rela di antara pihakpihak pelaku akad yang dilakukan secara verbal, tertulis, melalui korespondensi atau menggunakan cara-cara komunikasi modern.

d) Nisbah Keuntungan

Beberapa penjelasan terkait dengan nisbah keuntungan adalah:

- nisbah adalah besaran yang digunakan untuk pembagian keuntungan, mencerminkan imbalan yang berhak diterima oleh kedua pihak yang bermudharabah atas keuntungan yang diperoleh;

- perubahan nisbah harus berdasarkan kesepakatan kedua belah pihak;

- pemilik dana tidak boleh meminta pembagian keuntungan dengan menyatakan nilai nominal tertentu karena dapat menimbulkan riba.

\section{Jenis Mudharabah}

Menurut PSAK 105, terdapat 3 jenis mudharabah, yaitu mudharabah muqayyadah, mudharabah muthlaqah, dan mudharabah musytarakah yang akan dijelaskan berikut ini:

a. Mudharabah Muqayyadah

Bentuk kerjasama antara pemilik dana dan pengelola, dengan kondisi pengelola dikenakan pembatasan oleh pemilik dana dalam hal tempat, cara, dan/objek investasi. Dalam transaksi mudharabah muqayyadah, bank syariah bersifat sebagai agen yang menghubungkan shahibul maal dengan mudharib.

b. Mudharabah Muthlaqah

Bentuk kerjasama antara pemilik dana dan pengelola tanpa adanya pembatasan oleh pemilik dana dalam hal tempat, cara maupun objek investasi. Pemilik dana 
pemberi kewenangan yang sangat luas kepada mudharib untuk menggunakan dana yang diinvestasikan.

c. Mudharabah Musytarakah

Bentuk mudharabah dimana pengelola dana menyertakan modal atau dananya dalam kerjasama investasi. Akad musytarakah ini merupakan solusi dalam suatu usaha, pengelola dana memiliki modal yang dapat dikontribusikan dalam investasi.

\section{Manfaat Mudharabah}

Mudharabah memiliki manfaat dalam penerapan yang dilakukan oleh bank syariah. Adapun manfaat tersebut antara lain : (Yasin, 2009:196)

a. bank akan menikmati peningkatan bagi hasil pada saat keuntungan pengusaha meningkat;

b. bank tidak berkewajiban membayar bagi hasil kepada nasabah pendanaan secara tetap, tetapi disesuaikan dengan penerapan atau hasil usaha bank, sehingga bank tidak akan pernah mengalami negative spread;

c. pengambilan pokok pembiayaan disesuaikan dengan arus kas usaha nasabah, sehingga tidak memberatkan nasabah;

d. bank akan lebih selektif dan hati-hati mencari usaha yang benar-benar halal, aman, dan menguntungkan;

e. prinsip bagi hasil dalam mudharabah ini, dimana bank akan menagih penerima pembiayaan (nasabah) satu jumlah bunga tetap berapapun keuntungan yang dihasilkan nasabah, sekalipun merugi dan terjadi krisis ekonomi.

\section{Deposito Mudharabah}

\section{a. Pengertian Deposito}

Deposito merupakan dana yang dapat diambil sesuai dengan perjanjian berdasarkan jangka waktu yang telah disepakati. Balas jasa yang diberikan oleh bank untuk deposito lebih tinggi dibanding produk dana lainnya seperti giro dan tabungan. Dana deposito ini dianggap sebagai dana semi stabil. Artinya, penarikannya hanya dapat dilakukan pada waktu tertentu, yaitu apabila deposito diperjanjikan dalam jangka 
waktu 1 bulan, maka deposito tersebut dapat dicairkan setelah satu bulan. Misalnya, deposito ditempatkan pada 20 January 2013, maka jatuh tempo deposito tersebut baru ditarik pada 20 February 2013, yaitu satu bulan setelah deposito ditempatkan (Ismail, 2010:79).

Berdasarkan ketentuan Undang-Undang No 10 Tahun 1998 deposito didefinisikan simpanan yang penarikannya hanya dapat dilakukan pada waktu tertentu berdasarkan perjanjian nasabah menyimpan dengan bank atau pada saat jatuh tempo. Deposito merupakan produk dari bank yang memang ditujukan untuk kepentingan investasi dalam bentuk surat-surat berharga, sehingga dalam perbankan syariah akan memakai prinsip mudharabah (IKAPI, 2007:93).

\section{b. Pengertian Deposito Mudharabah}

Dalam perbankan syariah, produk berupa deposito hanya mendasarkan pada akad mudharabah, karena sifat spesifik dari deposito yang memang ditujukan untuk suatu investasi. Salah satu produk penghimpunan dana oleh bank syariah adalah deposito mudharabah. Nasabah akan mendapatkan keuntungan berupa bagi hasil yang besar sesuai dengan nisbah yang telah disepakati sesuai dengan awal perjanjian yang telah ditetapkan. Jangka waktu deposito mudharabah berkisar antara 1 bulan, 3 bulan, 6 bulan, dan 12 bulan (IKAPI, 2007:93-94).

Deposito mudharabah adalah simpanan dana dengan skema pemilik dana memercayakan dananya untuk dikelola bank dengan hasil yang diperoleh dibagi antara pemilik dana dan bank dengan nisbah yang disepakati sejak awal. Dalam transaksi penyimpanan deposito mudharabah, bank wajib memberitahukan kepada pemilik dana mengenai nisbah dan tata cara pemberian keuntungan dan atau perhitungan distribusi keuntungan serta risiko yang dapat timbul dari deposito tersebut (Yaya, dkk, 2014:55).

Deposito mudharabah merupakan dana investasi yang ditempatkan oleh nasabah yang tidak bertentangan dengan prinsip syariah dan penarikannya hanya dapat dilakukan pada waktu tertentu, sesuai dengan akad perjanjian yang dilakukan antara bank dan nasabah investor. Deposito, mudah diprediksi ketersediaan dananya karena terdapat jangka waktu dalam 
penempatannya. sifat deposito yaitu penarikannya hanya dapat dilakukan sesuai jangka waktunya, sehingga pada umumnya balas jasa yang berupa nisbah bagi hasil yang diberikan oleh bank untuk deposito lebih tinggi dibanding dengan tabungan mudharabah (Ismail, 2010:91).

Deposito berdasarkan akad mudharabah adalah: (Majelis Ulama Indonesia dalam Anisah, dkk, 2013)

1) dalam transaksinya nasabah bertindak sebagai shahibul maal atau pemilik dana, dan bank bertindak sebagai mudharib atau pengelola dana;

2) dalam kapasitasnya sebagai mudharib, bank dapat melakukanberbagaimacamusahayangtidakbertentangan dengan prinsip syari'ah dan mengembangkannya, termasuk di dalamnya mudharabah dengan pihak lain;

3) modal harus dinyatakan dengan jumlahnya dalam bentuk tunai dan bukan piutang;

4) pembagian keuntungan harus dinyatakan dalam bentuk nisbah dan dituangkan dalam akad pembukaan rekening;

5) bank sebagai mudharib menutup biaya operasional deposito dengan menggunakan nisbah keuntungan yang menjadi haknya;

6) bank tidak diperkenankan untuk mengurangi nisbah keuntungan nasabah tanpa persetujuan yang bersangkutan.

\section{c. Implementasi Prinsip Mudharabah dalam Produk Deposito Perbankan Syariah}

Deposito sebagai salah satu produk perbankan dalam perbankan syariah menggunakan skema mudharabah. Hal ini sejalan dengan tujuan dari nasabah menggunakan instrumen deposito yakni sebagai sarana investasi dalam upaya memperoleh keuntungan. Dalam kegiatan penghimpunan dana dalam bentuk deposito berdasarkan akad mudharabah berlaku persyaratan paling kurang sebagai berikut: (IKAPI, 2007:95-96)

1) bank bertindak sebagai pengelola dana dan nasabah bertindak sebagai pemilik dana;

2) dana disetor penuh kepada bank dan dinyatakan dalam jumlah nominal;

3) pembagian keuntungan dari pengelolaan dana investasi 
Analisis Faktor-Faktor yang Dipertimbangkan dalam ...

dinyatakan dalam bentuk nisbah;

4) pada akad tabungan berdasarkan mudharabah, nasabah wajib menginvestasikan minimum dana tertentu yang jumlahnya ditetapkan oleh bank dan tidak dapat ditarik oleh nasabah kecuali dalam rangka penutupan rekening;

5) nasabah tidak diperbolehkan menarik dana diluar kesepakatan;

6) bank sebagai mudharib menutup biaya operasional deposito dengan menggunakan nisbah keuntungan yang menjadi haknya;

7) bank tidak diperbolehkan mengurangi bagian keuntungan nasabah tanpa persetujuan nasabah yang bersangkutan; dan

8) bank tidak menjamin dana nasabah, kecuali diatur berbeda dalam perundang-undangan yang berlaku.

\section{d. Fitur dan Mekanisme Deposito berdasarkan Mudharabah}

Perbankan syariah menerapkan deposito berdasarkan akad mudharabah dan di dalam penerapannya terdapat fitur atau mekanisme yang telah ditetapkan oleh pihak bank. Adapun fitur maupun mekanisme tersebut, antara lain: (Soemitra, 2009:77)

1) bank bertindak sebagai pengelola dana dan nasabah bertindak sebagai pemilik dana;

2) pengelolaan dana oleh bank dapat dilakukan oleh bank sesuai batasan-batasan yang ditetapkan oleh pemilik dana (mudharabah muqayyadah) atau dilakukan tanpa batasanbatasan dari pemilik dana (mudharabah muthlagah);

3) dalam mudharabah muqayyadah harus dinyatakan secara jelas syarat-syarat dan batasan tertentu yang ditentukan oleh nasabah;

4) pembagian keuntungan dinyatakan dalam bentuk nisbah yang disepakati;

5) penarikan dana oleh nasabah hanya dapat dilakukan sesuai waktu yang disepakati;

6) bank dapat membebankan kepada nasabah biaya administrasi berupa biaya-biaya yang terkait langsung dengan biaya pengelolaan rekening antara lain biaya materai, cetak laporan transaksi dan saldo rekening, pembukaan, dan penutupan rekening; 
7) bank tidak diperkenankan mengurangi nisbah keuntungan nasabah tanpa persetujuan nasabah yang bersangkutan.

\section{e. PSAK 105}

PSAK 105bertujuan untuk mengatur perlakuanakuntansi dengan akad mudharabah (pengakuan, pengukuran, penyajian, dan pengungkapan)transaksi khusus yang berkaitan dengan aktivitas bank syariah. PSAK ini diterapkan untuk entitas yang melakukan transaksi mudharabah baik sebagai pemilik dana (shahibul maal) maupun pengelola dana (mudharib).

Menurut PSAK 105, mudharabahadalah akad kerjasama usaha antara dua pihak dimana pihak pertama (pemilik dana) menyediakan seluruh dana, sedangkan pihak kedua (pengelola dana) bertindak selaku pengelola, dan keuntungan dibagi diantara mereka sesuai kesepakatan sedangkan kerugian finansial hanya ditanggung oleh pemilik dana.

Contoh :

\begin{tabular}{|l|l|l|}
\hline Uraian & Jumlah & Metode Bagi Hasil \\
\hline Penjualan & 100 & Revenue Sharing \\
Harga Pokok Penjualan & 65 & \\
\hline Laba Kotor & 35 & \\
Biaya-biaya & 25 & \\
\hline Laba Rugi Bersih & 10 & Profit Sharing \\
\hline
\end{tabular}

Tabel 1 Contoh Perhitungan Bagi Hasil dengan Metode Revenue Sharing dan Profit Sharing

\section{Penelitian Terdahulu}

Menurut penelitian sebelumnya yang telah dilakukan oleh Oksita (2011), tentang faktor-faktor yang dipertimbangkan dalam penetapan besarnya nisbah bagi hasil pembiayaan mudharabah pada tiga BMT baitul maal wattamwil di Kabupaten Situbondo, yaitu BMT UGT Sidogiri Arjasa, BMT MMU Mangaran dan BMT Panji dapat diperoleh kesimpulan yaitu:

a. Urutan faktor yang paling dipertimbangkan dalam penentuan nisbah bagi hasil pada BMT Sidogiri adalah:

1) hubungan baik antara mitra dan BMT;

2) jangka waktu pengembalian; 
Analisis Faktor-Faktor yang Dipertimbangkan dalam ...

3) Besar kecilnya nominal pembiayaan;

4) sektor usaha yang dijalankan;

5) perkiraan resiko yang dihadapi;

6) besarnya jaminan mudharib.

b. Urutan faktor yang paling dipertimbangkan dalam penentuan nisbah bagi hasil pada BMT MMU Mangaran adalah:

1) hubungan baik antara mitra dan BMT;

2) jangka waktu pengembalian;

3) perkiraan resiko yang dihadapi;

4) sektor usaha yang dijalankan;

5) besarnya jaminan mudharib;

6) besar kecilnya nominal pembiayaan.

c. Urutan faktor yang paling dipertimbangkan dalam penentuan nisbah bagi hasil pada BMT Panji adalah :

1) jangka waktu pengembalian;

2) besar kecilnya nominal pembiayaan;

3) perkiraan resiko yang dihadapi;

4) hubungan baik antara mitra dan BMT;

5) sektor usaha yang dijalankan;

6) besarnya jaminan mudharib.

Dapat disimpulkan bahwa faktor-faktor yang dipertimbangkan dalam penentuan nisbah bagi hasil atas pembiayaan mudharabah pada BMT di Kabupaten Situbondo adalah:

a. besar kecilnya nominal pembiayaan;

b. jangka waktu pengembalian;

c. sektor usaha yang dijalankan;

d. besarnya jaminan mudharib;

e. perkiraan resiko yang dihadapi;

f. hubungan baik antara mitra dan BMT.

Menurut Bimo (2013), hasil dari penelitian yang dilakukan menunjukkan bahwa perlakuan akuntasi mudharabah yang diterapkan oleh BMT Bina Tanjung dapat dikatakan telah sesuai dengan PSAK 105. Kesesuaian tersebut terdapat pada karakteristik dan pengungkapan, kecuali pada pengakuan, pengukuran, dan penyajian, sedangkan untuk BMT UGT Sidogiri telah sesuai dengan PSAK 105. Kesesuaian tersebut terdapat pada karakteristik, pengakuan dan pengukuran, pengungkapan 
kecuali pada penyajian.

\section{Metode Penelitian}

\section{Jenis Penelitian}

Penelitian ini merupakan penelitian kualitatif analisis deskriptif, yaitu metode yang dilakukan dengan cara mengumpulkan, mempersiapkan, serta menganalisis data sehingga mendapat gambaran yang jelas mengenai masalah yang diteliti. Metode analisis deskriptif bertujuan untuk mendeskripsikan secara sistematis, faktual, dan akurat mengenai fakta-fakta, sifat-sifat serta hubungan antar fenomena yang diteliti (Menurut Nawawi, dalam Oksita 2011).

\section{Lokasi Penelitian}

Menjelaskan tempat, organisasi, satuan, atau lembaga yang dijadikan sasaran penelitian, disertai dengan pertimbangan alasan memilih lokasi tersebut. Pertimbangan yang dikemukakan selayaknya pertimbangan-pertimbangan ilmiah yang dikaitkan dengan permasalahan penelitian (Sanusi, 2011:197). Penelitian ini menggunakan perbankan syariah yang berada di kota Jember yang telah dipilih oleh penulis, yaitu BPR Syariah Asri Madani Nusantara yang berada di Jalan Sentot Prawirodirjo No.2 Jember

\section{Jenis dan Sumber Data}

\section{Jenis Data}

Adapun jenis data yang dilakukan penelitian ini adalah:

a. Data primer

Data primer merupakan data yang pertama kali dicatat dan dikumpulkan oleh peneliti (Sanusi, 2011:104). Data primer dalam penelitian ini didapatkan dari proses wawancara terhadap informan terkait yaitu Direktur sebagai informan utama dan Customer Service (CS), serta Kepala bagian Akuntansi sebagai informan pendukung pada BPR Syariah Asri Madani Nusantara.

b. Data Sekunder

Data penelitian yang diperoleh peneliti secara tidak langsung melalui media perantara atau diperoleh dan dicatat dari pihak lain maupun dokumen-dokumen (Sanusi, 2011:104). Pada penelitian ini, data sekunder 
Analisis Faktor-Faktor yang Dipertimbangkan dalam ...

diperoleh dari, laporan keuangan, PSAK 105 dan dokumen yang terkait yang sesuai dengan tujuan penulisan. Data sekunder ini dianalisis bersama dengan data primer.

\section{Sumber Data}

Dalam penelitian ini, data primer diperoleh dari wawancara dengan Direktur dan Customer Service(CS) serta Kepala bagian Akuntansi di BPR Syariah Asri Madani Nusantara.Penulis memilih direktur karena merupakan pemimpin perusahaan yang mengetahui kebijakan-kebijakan dan mengetahui informasi penting yang terdapat di perusahaan. CSsalah satu tugasnya adalah melayani jasa perbankan khususnya tabungan dan deposito kepada nasabah, serta kepala bagian akuntansi yang mengetahui tentang perumusan kebijakan akuntansi dan melaksanakan penyusunan laporan keuangan, sehingga ketiga subjek tersebut merupakan informan yang mengetahui banyak tentang perihal mengenai sistem bagi hasil dan perlakuan akuntansi. Data sekunder diperoleh dari dokumen terkait,laporan keuangan tahunan, buku profil bank, dan PSAK 105 yang sesuai dengan tujuan penulisan. Data sekunder ini dianalisis bersama dengan data primer.

\section{Pembahasan}

1. Faktor-faktor yang Dipertimbangkan dalam Penentuan Nisbah Bagi Simpanan Deposito Mudharabah pada BPR Syariah Asri Madani Nusantara

Dalam menentukan seberapa besar nisbah bagi hasil reguler maupun spesial nisbah yang akan diberikan kepada nasabah, terdapat beberapa hal yang harus dipertimbangkan dalam penentuan nisbah bagi hasil deposito mudharabah, yaitu :

\subsection{Rate yang Berlaku di Bank Syariah Lainnya maupun} Bank Konvensional

Rate yang diberlakukan minimal sama atau mendekati bank yang terdapat pada daerah Jember atau di sekitar lokasi kantor BPRS tersebut. Sehingga rate yang ditetapkan oleh pihak bank kepada nasabah dapat bersaing dengan baik. Dengan diperhitungkan bahwa BPRS tetap mengalami keuntungan yang 
stabil bahkan semakin meningkat setiap bulannya.Rate yang dipertimbangkan diusahakan tidak sampai dibawah rata-rata yang terdapat di bank-bank lainnya karena juga akan merugikan bank itu sendiri.

Misalkan BPRS Asri melihat rate yang pada bulan January di bank syariah lainnya maupun bank konvensional sebesar 6,161 yang akan mendapatkan bagi hasil sekitar $28 \%$, dengan perhitungan seperti berikut ini:

$$
\begin{aligned}
\text { Nisbah Nasabah }= & \frac{\text { BH per mill }}{\text { Hasil Investasi per mill }} \\
=\frac{5 \text { [2 } 23}{18 \text { 团 } 69} & \\
& =0,279 \text { atau } 0,28 \\
& =28 \% \text { (dalam prosentase) }
\end{aligned}
$$

Maka BPRS Asri menetapkan rate atas pertimbangan yang direksi tetapkan sekitar 5,061 atau sebesar 6,381 yang kirakira nasabah akan mendapatkan nisbah sebesar $29 \%$ dengan perhitungan seperti berikut ini:

$$
\begin{aligned}
\text { Nisbah Nasabah } & =\frac{\text { BH per mill }}{\text { Hasil Investasi per mill }} \\
& =\frac{5 \text { [ } 42}{18 \text { 圆 } 69}
\end{aligned}
$$

$$
\begin{aligned}
& =0,289 \text { atau } 0,29 \\
& =29 \% \text { (dalam prosentase) }
\end{aligned}
$$

Kebijakan tersebut ditetapkan karena BPRS Asri menginginkan sebagian besar nasabah maupun calon nasabah akan lebih berminat untuk mendepositokan uangnya dengan mendapatkan keuntungan bagi hasil yang cukup besar atau sama dengan bank syariah maupun bank konvensional lainnya. Rate yang dimaksud oleh BPRS Asri adalah bukan rate yang biasa berada di bank konvensional, tetapi hanya sebagai pedoman rate untuk mempertimbangkan penetapan ekuivalen rate yang setara dengan rate yang terdapat di bank konvensional pada BPRS Asri yang nantinya akan menentukan seberapa besar nasabah akan mendapatkan bagi hasil sesuai dengan besarnya nisbah. 
Analisis Faktor-Faktor yang Dipertimbangkan dalam ...

\subsubsection{Berdasarkan Kinerja Keuangan BPR Syariah Asri Madani Nusantara}

BPRS Asri menganalisa kinerja keuangan yang terjadi pada setiap bulannya terutama mengenai jumlah likuiditas yang terdapat di dalam neraca apakah dalam keadaan meningkat atau menurun, karena jika likuiditas bank mengalami kenaikan maka bank akan menaikkan nisbah bagi hasil terutama dari dana yaitu deposito dengan akad mudharabah dari kesetaraan ekuivalen rateyang sudah ditetapkan untuk mengamankan posisi keuangan.Kenaikan tersebut dilakukan untuk memperoleh keuntungan dan kinerja keuangan tetap terjaga dengan baik dan stabil.Pada saat bank mengalami kenaikan likuiditas yang cukup tinggi, maka pihak bank mengambil suatu kebijakan agar tidak mengalami kerugian, salah satunya adalah menurunkan ekuivalen rate. Hal tersebut berhubungan dengan besarnya nisbah bagi hasil yang akan diberikan kepada nasabah.

(Dalam Ribuan Rp)

\begin{tabular}{|l|l|l|l|}
\hline No & Pos-Pos & $\begin{array}{l}\text { Posisi } \\
\text { Desember } \\
\mathbf{2 0 1 4} \\
\text { Unaudited }\end{array}$ & $\begin{array}{l}\text { Posisi } \\
\text { Desember } \\
\mathbf{2 0 1 3} \\
\text { Unaudited }\end{array}$ \\
\hline 1 & Kewajiban Segera & 195.072 & 119.723 \\
\hline 2 & Tabungan Wadiah & 0 & 0 \\
\hline 3 & $\begin{array}{l}\text { Kewajiban Kepada Bank } \\
\text { Indonesia }\end{array}$ & 0 & 0 \\
\hline 4 & Kewajiban Lain-lain & 4.333 .668 & 3.533 .891 \\
\hline 5 & $\begin{array}{l}\text { Pembiayaan atau Pinjaman Yang } \\
\text { Diterima }\end{array}$ & 230.502 & 375.000 \\
\hline 6 & Pinjaman Subordinasi & 0 & 0 \\
\hline 7 & Modal Pinjaman & 0 & 0 \\
\hline 8 & Dana Investasi Tidak Terikat: & & \\
\hline & a. Tabungan Mudharabah & 4.883 .879 & 4.818 .032 \\
\hline & b. Deposito Mudharabah & 2.785 .100 & 1.626 .100 \\
\hline 9 & Ekuitas: & & \\
\hline & a. Modal Disetor & 1.191 .500 & 1.100 .000 \\
\hline & b. Tambahan Modal & 0 & 0 \\
\hline & c. Selisis Penilaian Kembali & 0 & 0 \\
\hline
\end{tabular}


Nur Hisamuddin dan Andi A.

\begin{tabular}{|l|l|l|l|}
\hline & d. Cadangan & 98.575 & 63.938 \\
\hline & e. Saldo Laba (Rugi) & 423.010 & 347.373 \\
\hline & JUMLAH PASIVA & 14.141 .306 & 11.984 .057 \\
\hline
\end{tabular}

Tabel 1 Neraca Pasiva

Sumber: Laporan Neraca Publikasi Per-Desember 2014

\begin{tabular}{|l|l|l|l|}
\hline & Pos-Pos & $\begin{array}{l}\text { Posisi } \\
\text { Desember } \\
\mathbf{2 0 1 4} \\
\text { Unaudited }\end{array}$ & $\begin{array}{l}\text { Posisi } \\
\text { Desember } \\
\mathbf{2 0 1 3} \\
\text { Unaudited }\end{array}$ \\
\hline 1 & Kas & 94.939 & 46.886 \\
\hline 2 & Penempatan pada Bank Indonesia & 0 & 0 \\
\hline 3 & Penempatan pada Bank Lain & 1.411 .526 & 1.593 .106 \\
\hline 4 & Piutang Murabahah & 11.219 .400 & 9.612 .291 \\
\hline 5 & Piutang Salam & 0 & 0 \\
\hline 6 & Piutang Istishna & 0 & 0 \\
\hline 7 & Pembiayaan Mudharabah & 0 & 0 \\
\hline 8 & Pembiayaan Musyarakah & 0 & 0 \\
\hline 9 & Ijarah & 247.722 & 55.695 \\
\hline 10 & Qardh & 6.000 & 63.150 \\
\hline 11 & Piutang Multijasa & 412.744 & 376.332 \\
\hline 12 & $\begin{array}{l}\text { Penyisihan Penghapusan } \\
\text { Aktiva-/- }\end{array}$ & 104.209 & 82.707 \\
\hline 13 & Aktiva Istishna & 0 & 0 \\
\hline 14 & Persediaan & 0 & 0 \\
\hline 15 & Aktiva Tetap dan Inventaris & 905.812 & 395.218 \\
\hline 16 & $\begin{array}{l}\text { Akumulasi Penghapusan Aktiva } \\
\text { Tetap-/- }\end{array}$ & 292.543 & 211.821 \\
\hline 17 & Aktiva Lain-lain & 239.915 & 135.907 \\
\hline & JUMLAH AKTIVA & 14.141 .306 & 11.984 .057 \\
\hline
\end{tabular}

Tabel 2 Neraca Aktiva

Sumber: Laporan Neraca Publikasi Per-Desember 2014 162

Jurnal Bisnis dan Manajemen Islam 
Dari laporan neraca diatas,bisa dilihat bahwa likuiditas bank dari tahun 2013 ke tahun 2014 mengalami penurunan sebesar 0,046, sepanjang tahun 2013 likuiditas bank sebesar 1,006 dan tahun 2014 sebesar 0,96. Penurunan likuiditas tersebut mempengaruhi tingkat penentuan nisbah yang akan ditetapkan oleh pihak bank. Sehingga pada tahun 2015 mendatang, kenaikan ekuivalen rate akan dipertimbangkan dengan lebih baik lagi agar bank tidak mengalami kerugian tetapi ada kemungkinan bahwa bank akan menaikkan ekuivalen rate pada tahun berikutnya karena bisa dilihat bahwa likuiditas bank sudah mengalami penurunan.. Berikut perhitungan dari likuiditastahun 2013 dengan menggunakan current ratio:

a. Aktiva lancar yang terdapat di laporan neraca BPRS Asri Madani Nusantara, yaitu:

Tahun 2013 (dalam ribuan)

1. Kas 46.886

2. Piutang Murabahah $\quad$ : 9.612 .291

3. Piutang Multijasa : 376.332 TOTAL : 10.035 .509 .000

b. Hutang Lancar yang terdapat di laporan neraca BPRS Asri Madani Nusantara, yaitu:

Tahun 2013(dalam ribuan)

1. Kewajiban Segera : 119.723

2. Kewajiban Lain-lain $\quad$ : 3.533 .891

3. Tabungan Mudharabah : 4.818 .032

4. Deposito Mudharabah : 1.626 .100 TOTAL : 10.097 .746 .000

Current Ratio $=\mathrm{x} 100 \%$

$=\times 100 \%$

$=1,006 \%$

Berikut perhitungan dari likuiditas tahun 2014 dengan menggunakan current ratio :

a. Aktiva lancar yang terdapat di laporan neraca BPRS Asri Madani Nusantara, yaitu:

Tahun 2014 (dalam ribuan)
1. Kas
2. Piutang Murabahah
11.219 .400
3. Piutang Multijasa
412.744 
TOTAL

: 11.727.083.000

b. Hutang Lancar yang terdapat di laporan neraca BPRS Asri Madani Nusantara, yaitu:

Tahun 2014 (dalam ribuan)

1. Kewajiban Segera

2. Kewajiban Lain-lain

3. Tabungan Mudharabah : $\quad 4.883 .879$

4. Deposito Mudharabah : $\quad 2.785 .100$

TOTAL : 12.197 .719 .000

Current Ratio $=\times 100 \%$

$=\times 100 \%$

$=0,96 \%$

Selain itu, tidak hanya dilihat dari segi liabilitas saja tetapi pihak bank harus memperhatikan mengenai jatuh tempo deposito mudharabah yang akan diberikan bagi hasilnya yang telah dianalisis oleh bank mengenai seberapa besar jumlah pendapatan yang harus dibagi kepada para nasabahnya agar tidak lebih besar dari pendapatan dari hasil pembiayaan yang didapatkan oleh pihak bank itu sendiri karena hal tersebut akan mempengaruhi laba yang akan didapatkan oleh bank.

\subsection{Hubungan Baik antara Bank dengan Mitra atau Nasabah}

Dengan menjaga hubungan baik dengan nasabah utama yang loyal kepada bank khususnya dalam menginvestasikan uangnya pada deposito mudharabah. Nasabah utama biasanya mempunyai hubungan baik dengan pihak bank, sehingga dalam penentuan nisbahnya berbeda dengan nasabah biasa. Direksi mempertimbangkan kenaikan nisbah kepada nasabah-nasabah tertentu dengan tujuan agar nasabah tersebut tetap berinvestasi di BPR Syariah Asri Madani Nusantara. Hubungan yang baik yang dibina oleh nasabah dengan bank akan cukup mempengaruhi pihak direksi untuk mempertimbangkan seberapa besar nisbah yang didapatkan.

Bukan berarti setiap nasabah yang memiliki hubungan baik dengan pihak bank akan mendapatkan kenaikan nisbah, tetapi juga dilihat bagaimana kondisi keuangan bank pada bulan tersebut. Kenaikan nisbah yang didapatkan oleh nasabah tidak berdasarkan atas keinginan nasabah itu sendiri melainkan 
atas kesepakatan antara kedua belah pihak yang bersangkutan. Selain itu, jika nasabah ingin mendapatkan pertimbangan dari direksi mengenai nisbah yang didapatkan, nasabah reguler juga bisa melakukan perjanjian dengan bank agar mendapatkan spesial nisbah yang minimal mendepositokan uangnya lebih dari sama dengan Rp. 150.000 .000 (seratus lima puluh juta) dengan jangka waktu 1 bulan ARO dengan nisbah maksimal sebesar $60 \%$. Meskipun bank menetapkan maksimal dari spesial nisbah sebesar $60 \%$, bukan berarti direksi akan memberikan secara langsung prosentase nisbah tersebut, melainkan juga harus mempertimbangkan kinerja keuangan yang sedang terjadi. Misalkan nasabah yang sangat loyal dan memiliki hubungan yang baik dengan pihak bank mendepositokan uangnya sebesar 200.000.000 (dua ratus juta) dengan permintaan spesial nisbah yang cukup tinggi dan mendapatkan sekitar 35\% dalam jangka waktu deposito 3 bulan, berikut contoh perhitungannya.

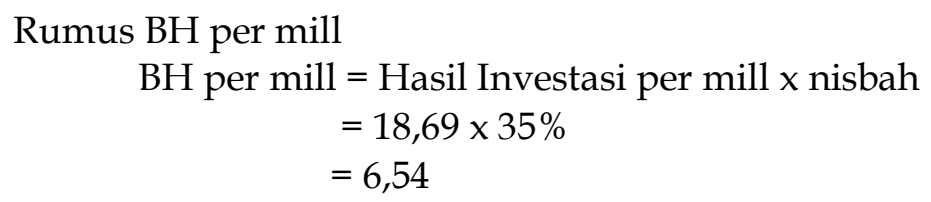

Rumus Nisbah Nasabah

$$
\begin{aligned}
\text { Nisbah Nasabah }= & \frac{\text { BH per mill }}{\text { Hasil Investasi per mill }} \\
=\frac{6 \text { 团 } 54}{18 \text { 69 }} & \\
& =0,349 \text { atau } 0,35 \\
& =35 \% \text { (dalam prosentase) }
\end{aligned}
$$

\subsection{Rencana Kerja Anggaran Tahunan (RKAT) BPR Syariah Asri Madani Nusantara}

Bank membuat rencana kerja anggaran tahunan dengan melihat rencana kerja pada tahun-tahun sebelumnya. Seberapa pesat bank mengalami kenaikan setiap tahunnya dengan rencana yang sudah diberlakukan pada tahun tersebut yang dilihat berdasarkan prosentase.Selain itu pada RAT juga dibahas tentang keadaan perusahaan atau bank dalam kondisi 
kesulitan likuiditas atau tidak, yang berarti jika pihak bank sedang mengalami kesulitan dalam memenuhi kewajiban jangka pendeknya atau utang yang segera harus dibayar dengan harta lancarnya. Sehingga, pada rapat tersebut BPRS tidak berani ambil resiko untuk menaikkan ekuivalen rate yang berdampak pada pemberikan nisbah yang cukup tinggi terhadap nasabah, karena hal tersebut akan merugikan bank itu sendiri.

Dari rapat tersebut akan dibicarakan pula bagaimana ekivalen rate yang akan ditetapkan setiap bulannya dengan melihat rate di bank syariah maupun bank konvensional lainnya dan dirangkum dalam peningkatan rate setiap tahunnya. Pada RAT, juga membicarakan tentang rate yang akan ditetapkan oleh nasabah untuk besarnya suatu nisbah dalam bagi hasil dan harus disetujui oleh para pemegang saham.

Para pemegang saham melihat setiap tahunnya deposito mudharabah akan mengalami kenaikan atau tidak. Jika tidak mengalami kenaikan, maka dalam penentuan besarnya nisbah akan dimainkan di dalam rate yang akan ditetapkan.Dalam menentukan rate tersebut juga harus berdampak yang baik untuk pihak bank agar tidak mengalami kerugian.

\subsection{Penempatan Dana antar Bank (antar kota seluruh Indonesia)}

Adanya penempatan dana antar bank oleh BPR Syariah Asri Madani Nusantara yang nantinya akan menguntungkan untuk memperoleh laba atas deposito mudharabah yang penenempatan dana tersebut berasal dari dana para nasabah yang mendepositokan uangnya. Dana tersebut diputar untuk mendapatkan keuntungan bagi hasil yang akan didapatkan oleh pihak bank. Ketentuan nisbah yang diperoleh juga berdasarkan seberapa besar bank mendapatkan pendapatan dari perputaran dana tersebut agar likuiditas bank tetap berjalan stabil tidak mengalami peningkatan.

Pihak bank dalam melakukan penempatan dana tetap memperhitungkan jatuh tempo minimal sama atau lebih pendek dari jangka waktu nasabahnya agar perputaran sistem penempatan dana yang dilakukan tidak menimbulkan kerugian dan tetap memberikan nasabah dengan nisbah yang cukup atau bisa juga ekuivalen rate yang ditetapkan akan meningkat dan mendapatkan prosentase nisbah yang cukup tinggi. 
Misalkan pada saat nasabah mendepositokan sebesar 75.000 .000 (tujuh puluh lima juta) dengan jangka waktu 1 bulan. Maka pihak bank akan melakukan perputaran dana ke bank lainnya sesama bank syariah untuk mendapatkan keuntungan bagi hasil. Pada saat uang pendepositoan dari para nasabah sudah disalurkan ke bank syariah lainnya dengan jenis simpanan yang sama yaitu deposito mudharabah, bank harus memilih jangka waktu yang sama pula yaitu 1 bulan agar pada saat jatuh tempo nasabah di BPRS Asri dengan membagikan bagi hasil kepada nasabah secara tepat waktu dan dana tersebut akan terus mengalami perputaran dan BPRS Asri juga mendapatkan keuntungan bagi hasil dari bank lainnya.

\subsection{Perlakuan Akuntansi Berdasarkan PSAK 105pada Deposito Mudharabah sebagai Penghimpunan Dana di BPR Syariah Asri Madani Nusantara}

\subsubsection{Pengakuan dan Pengukuran}

Pengakuan dan Pengukuran pada BPR Syariah Asri Madani Nusantara dapat dilihat pada tabel dibawah ini.

\begin{tabular}{|l|l|l|}
\hline PSAK 105 & Sesuai & $\begin{array}{l}\text { Tidak } \\
\text { Sesuai }\end{array}$ \\
\hline $\begin{array}{l}\text { Dana yang diterima dari pemilik dana } \\
\text { dalam akad mudharabah diakui sebagai } \\
\text { dana syirkah temporer sebesar jumlah kas } \\
\text { atau nilai wajar aset nonkas yang diterima. } \\
\text { Pada akhir periodeakuntansi, dana syirkah } \\
\text { temporer diukur sebesar nilai tercatatnya. } \\
\text { (Paragraf 25) }\end{array}$ & $\sqrt{ }$ & \\
\hline $\begin{array}{l}\text { Jika pengelola dana menyalurkan dana } \\
\text { syirkahtemporer yang diterima maka } \\
\text { pengelola dana mengakuisebagai aset } \\
\text { sesuai ketentuan pada paragraf 12-13. } \\
\text { (Paragraf 26) }\end{array}$ & $\sqrt{ }$ & \\
\hline $\begin{array}{l}\text { Hak pihak ketiga atas bagi hasil } \\
\text { dana syirkahtemporer yang sudah } \\
\text { diperhitungkan tetapi belumdibagikan } \\
\text { kepada pemilik dana diakui sebagai } \\
\text { kewajibansebesar bagi hasil yang menjadi } \\
\text { porsi hak pemilik dana. }\end{array}$ & & \\
(Paragraf 29) & & \\
\hline
\end{tabular}




\begin{tabular}{|l|l|l|}
\hline $\begin{array}{l}\text { Kerugian yang diakibatkan oleh kesalahan } \\
\text { ataukelalaian pengelola dana diakui } \\
\text { sebagai beban pengelola dana. } \\
\text { (Paragraf 30) }\end{array}$ & $\sqrt{ }$ & \\
\hline
\end{tabular}

Tabel 3 Daftar Pengakuan dan Pengukuran Penghimpunan Dana Sumber: PSAK 105serta Laporan Keuangan bulan Desember 2014

Dari tabel diatas dapat diketahui bahwa BPR Syariah Asri Madani Nusantara menerima dana yang diperoleh dari nasabah berupa deposito dengan akad mudharabah, dana tersebut akan diakui sebesar jumlah kas yang diterima dengan nisbah bagi hasil yang sudah disepakati, karena dana syirkah temporer merupakan dana yang diberikan oleh nasabah kepada pihak bank. Dana tersebut akan dikelola dan kedua belah pihak mendapatkan keuntungan sesuai dengan kesepakatan. Pada akhir periode akuntansi, dana syirkah temporer diukur sebesar nilai tercatatnya. Jika BPRS Asri menerima dana syirkah temporer, maka dana tersebut akandiakui oleh pihak bank sebagai investasi mudharabah. Diakui sebagai investasi mudharabah karena dana tersebut akan disalurkan lagi oleh pihak bank untuk diberikan lagi kepada pengelola dana, karena posisi bank adalah sebagai shahibul maal. Sehingga bank mengalami perputaran keuangan yang pada nantinya jumlah dana yang terkumpul akan diberikan kepada pemilik dana (shahibul maal) pada saat bank berada di posisi sebagai pengelola dana (mudharib) yang berupa bagi hasil dan jumlah pengendapan uang deposito mudharabah yang sesuai dengan waktu jatuh tempo.

Pada saat waktu jatuh temponasabah belum mendapatkan hak bagi hasilnya yang didapatkan dari BPRS Asri, maka diakui sebagai kewajiban sebesar jumlah bagi hasil yang menjadi porsi hak nasabah itu sendiri sesuai dengan kesepakatan diawal. Di dalam neraca pasiva pihak bank mengakui sebagai pos kewajiban segera. Jika pada saat BPRS Asri meyalurkan dana syirkah temporer tersebut ke dalam entitas usaha yang dipilih bank maupun yang dipilih sendiri atas permintaan nasabah itu sendiri, kemudian mengalami kerugian yang tidak disengaja, maka kerugian akan ditanggung olehpihak bank sebagai beban pengelola dana, karena pada saat itu bank adalah sebagai pengelola dana dan mengelola dana tersebut yang diakui bank 
Analisis Faktor-Faktor yang Dipertimbangkan dalam ...

sebagai investasi mudharabah.

\subsubsection{Penyajian}

Penyajian akuntansi mudharabahpada BPR Syariah Asri Madani Nusantara dapat dilihat pada tabel dibawah ini.

\begin{tabular}{|c|c|c|}
\hline PSAK 105 & Sesuai & $\begin{array}{l}\text { Tidak } \\
\text { Sesuai }\end{array}$ \\
\hline $\begin{array}{l}\text { Pengelola dana menyajikan transaksi } \\
\text { mudharabah } \\
\text { dalam laporan keuangan: } \\
\text { a. dana syirkah temporer dari pemilik } \\
\text { dana disajikansebesar nilai tercatatnya } \\
\text { untuk setiap jenismudharabah; } \\
\text { b. bagi hasil dana syirkah temporer } \\
\text { yang sudahdiperhitungkan tetapi } \\
\text { belum diserahkan kepadapemilik } \\
\text { dana disajikan sebagai pos bagi hasil } \\
\text { yangbelum dibagikan di kewajiban. }\end{array}$ & $\sqrt{ }$ & $\sqrt{ }$ \\
\hline (Paragraf 37) & & \\
\hline
\end{tabular}

Tabel 4 Daftar Penyajian Penghimpunan Dana

Sumber: PSAK 105serta Laporan Keuangan per Desember 2014

Dari tabel diatas dapat diketahui bahwa penyajian atas laporan keuangan tidak sesuai dengan ketentuan PSAK 105. Dana syirkah temporer dari nasabah yang diberikan pada BPRS Asri disajikan sebesar nilai tercatatnya pada akad mudharabah saja, dicatat sebagai pos deposito mudharabah pada dana investasi tidak terikat, karena BPR masih menggunakan sitem PSAK 59, karena jenis produk yang terdapat di BPRS Asri Madani Nusantara tidak terlalu banyak. Adanya keterbatasan produk tersebut karena melihat seberapa banyak minat nasabah untuk mendepositokan uangnya. BPRS Syariah tidak mencantumkan dalam neraca passiva berbagai macam jenis mudharabah yang ada, seperti muthlaqah, muqayyadah, dan musytarakah. Sehingga nasabah mendepositokan uangnya hanya diberi akad mudharabah dan tidak diberi produk deposito dengan jenis mudharabah yang sesuai dengan PSAK 105 tersebut. Selain iti, bagi hasil dana syirkah temporer yang sudah diperhitungkan tetapi belum diberikan kepada nasabah, pihak bank dalam penyajian neracadisajikan dalam bentuk pos bagi hasil yang belum 
dibagikan di kewajiban tetapi nama pos nya adalah kewajiban segera. Sehuna penyajian ini sesuai dengan PSAK 105.BPRS Asri menetapkan kebijakan bahwa pembagian bagi hasil yang akan diberikan kepada nasabah pada saat akhir bulan dicantumkan dalam pos kewajiban segera.

\subsubsection{Pengungkapan}

\begin{tabular}{|l|l|l|}
\hline PSAK 105 & Sesuai & $\begin{array}{l}\text { Tidak } \\
\text { Sesuai }\end{array}$ \\
\hline $\begin{array}{l}\text { Pengelola dana mengungkapkan hal-hal } \\
\text { terkaittransaksi mudharabah, tetapi tidak } \\
\text { terbatas, pada: } \\
\text { a. isi kesepakatan utama usaha }\end{array}$ & & \\
mudharabah, seperti porsi dana, \\
pembagian hasil usaha, aktivitas \\
usahamudharabah, dan lain-lain; \\
b. rincian dana syirkah temporer yang \\
diterima berdasarkan jenisnya. & & \\
(Paragraf 39) & & \\
\hline
\end{tabular}

Tabel 5 Daftar Pengungkapan Penghimpunan Dana

Sumber: PSAK 105 serta Laporan Keuangan per Desember 2014

Dari tabel diatas menunjukkan bahwa pengungkapan yang dilakukan oleh BPR Syariah Asri Madani Nusantara dalam laporan keuangannyasudah sesuai dengan PSAK 105. Pengelola dana yaitu pihak bank mengungkapkan hal-hal yang terkait dengan transaksi mudharabah, yaitu pada saat pihak bank dengan nasabah melakukan kesepakatan, hal yang harus ditransparasikan kepada nasabah sebagai pemilik dana seperti porsi dana yang di depositokan sesuai jangka waktu yang dipilih, pembagian bagi hasil untuk kedua belah pihak yang mencantumkan seberapa besar nisbah yang didapat oleh nasabah. Selain itu, nasabahjuga harus mengetahui dana tersebut disalurkan dalam jenis usaha seperti apa, atau nasabah itu sendiri dapat memilih jenis usaha yang akan disalurkan oleh pihak bank. Rincian dana syirkah temporer yang berupa deposito untuk dikelola oleh pihak bank diterima berdasarkan akad mudharabah.

\section{Simpulan, Saran}

1. Simpulan

Berdasarkan pembahasan sebelumnya, kesimpulan dalam penelitian ini adalah sebagai berikut: 
Analisis Faktor-Faktor yang Dipertimbangkan dalam ...

Dapat disimpulkan bahwa faktor-faktor yang dipertimbangkan dalam penentuan nisbah bagi hasil deposito mudharabah pada BPR Syariah Asri Madani Nusantara adalah:

a. rate yang Berlaku di Bank Syariah lainnya maupun Bank Konvensional;

b. berdasarkan kinerja keuangan;

c. hubungan baik antara bank dengan mitra atau nasabah;

d. rencana kerja anggaran tahunan;

e. penempatan dana antar Bank (antar kota seluruh Indonesia);

f. kondisi makro ekonomi.

Dari hasil pembahasan yang telah diuraikan pada bab sebelumnya, bahwa terdapat beberapa perlakuan akuntansi yang sesuai dengan penerapan PSAK105 pada BPR Syariah Asri Madani Nusantara yaitu pengakuan dan pengukuran serta pengungkapan. Hanya saja yang tidak sesuai adalah penyajiannya, karena dana syirkah temporer dari nasabah yang diberikan pada BPRS Asri disajikan sebesar nilai tercatatnya pada akad mudharabah saja.BPRS Asri Madani Nusantara dalam laporan keuangannya masih menggunakan PSAK 59, hal ini terlihat dari laporan neraca bahwa deposito mudharabah ditentukan dalam pos dana investasi tidak terikat. Sedangkan dalam PSAK 105, deposito mudharabah merupakan dana syirkah temporer.

\section{Saran}

Bagi peneliti selanjutnya lebih menekankan pada konsep yang bersifat umum untuk diberitahukan kepada para pembaca, tetapi harus sesuai dengan kadar yang seharusnya dan tidak melanggar privacy dari Bank Syariah itu sendiri. 


\section{DAFTAR PUSTAKA}

Arikunto, Suharsimi. 2011, Prosedur Penelitian - Suatu Pendekatan Praktik. Penerbit/Publisher: Rhineka Cipta

Ghozali, Imam. 2005. Aplikasi Analisis Multivariate dengan Program SPSS edisi 3. Semarang: BP UNDIP

Griffin Jill, 2005, Customer Loyalty Menumbukan dan Mempertahankan Kesetiaan Pelanggan, Jakarta: Erlangga

Hansemark, Ove C. and Marie Albinsson. 2004, Customer Satisfaction and Retention: the experience of individual employess. Managing Service Quality Journal

ICSA, http://www.icsaindo.com/winner/icsa_2014.html, diakses 20 April 2015

Internasional Data Corporation., https://www.idc.com, diakses 20 April 2015

Kurniasari, Nina. dan Ernawati, Nina., 2012, Pengaruh Kepuasan Pelanggan, Kepercayaan, Dan Harga Terhadap Loyalitas Pelanggan Laundry Kencling Semarang, Vol. No. 3, Mei 2012

Kotler, Philip dan Armstrong, Gary.1999, Prinsip-Prinsip Pemasaran Edisi 12, Penerbit : Erlangga. 2011, Perilaku Konsumen Teori dan Penerapannya dalam Pemasaran, Penerbit : Ghalia Indonesia.

Sumarwan, Ujang

Mowen,J.C., dan Minor, M., 2001,Perilaku Konsumen,edisi 5, Jakarta: PT Penerbit Erlangga

Mowen. J. C., dan Minor, M., 2002, Perilaku Konsumen, Jilid 1 , Jakarta: PT Penerbit Erlangga

Mudrajad, Kuncoro, 2004, Metode Kuantitatif Teori dan Aplikasi Untuk Bisnis dan Ekonomi, Edisi Kedua, UPP APP YKPN, Yogyakarta.

Peter, J.P., dan Olson, J.C., 2000, Perilaku Konsumen dan Strategi 
Pemasaran, Jakarta: Erlangga

Riset Global Neilsen., http://teknologi.news.viva.co.id/news/ read/433547-hasil-survei-kebiasaan-pengguna-smartphone-di-indonesia, diakses tanggal 15 Mei 2015

Setiadi, N.J., 2003, Perilaku Konsumen, Jakarta: Kencana Prena- 
Analisis Faktor-Faktor yang Dipertimbangkan dalam ...

\section{da Media Grup}

Siswoyo, Erik, 2009,Analisis Pengaruh Kualitas Pelanggan, Kepercayaan Dan Kepuasan Nasabah Terhadap Loyalitas Nasabah Pada PT Bank Jateng Pemuda Semarang

Sujadna, 2005, Metode Statistika, Bandung:Tarsito

Sugiyono, 2007, Metode Penelitian Kuantitatif dan R\&D, Bandung: CV. Alfabeta 